\title{
Four Transcendental Illusions of the Digital World: A Derridean Approach
}

\author{
Susanna Lindberg | ORCID: 0000-0003-3093-6056 \\ Professor of Continental Philosophy, Leiden University, Leiden, \\ The Netherlands \\ s.e.lindberg@phil.leidenuniv.nl
}

\begin{abstract}
This article considers the remote meeting technologies that have become the unavoidable framework of (academic) work during the CoviD-19 epidemic. I analyze them with the help of Jacques Derrida's concepts, thus also illustrating the reach of the latter. The article presents four "transcendental illusions" as supporting the digital world and, according to Derrida, experience. The illusion of proximity: digitality relies on a haptocentric illusion but it also reveals the distance at the heart of touching. The illusion of presence: digitality functions under the illusion of presence, but it also reveals the spectrality of digital presence. The illusion of a complete memory: although the Internet appears to be a total memory, it is really an archive, that is, a finite set of traces. The illusion of worldwide community: teletechnologies pretend to constitute a universal place, but they only generate a finite dis-place of common alienation.
\end{abstract}

\section{Keywords}

digital technologies - touch - Derrida - transcendental - technicity

For those working or studying at university, but also for numerous others, the most concrete change brought about by the COVID-19 pandemic has been the total digitalization of the entirety of working life. Working online is nothing new (for a long time much of our work has consisted in online writing, reading and communicating), but shifting all human contact, or at least all professional contact (meetings, seminars, teaching, supervision, exams ...) online is new. In the blink of an eye we have learnt to use Zoom, Teams, Meet, Skype 
and other remote meeting technologies and we have found ourselves simultaneously pleased by the possibility of working without leaving our home and frustrated by the thin and sterile kind of communication generated by such digital meetings. The digital community is the most concrete illustration of an epidemic community which at the same time fears touching and craves contact.

In this essay I will analyze quasi-transcendental structures first discovered by Jacques Derrida that the digitally organized community illustrates particularly well. I will not study the psychological, sociological and political consequences of digitalization, because one needs to be an expert in these domains in order to arrive to anything better than the superficial criticism or enthusiasm that has filled our virtual coffee rooms during the remote working experience. Instead, I am taking a number of well-known affective phenomena associated with remote working technologies as an evident starting point of a phenomenological investigation that aims at clarifying their transcendental conditions. It is obvious that our psychological and affective states have been modified by the present technological situation. While lecturing and learning through remote meeting technologies, we have feelings akin to those of a teenager on a smartphone (although we pretend to control them better) who is thrilled by the possibility of sneaking into a digital crowd and addressing unknown people through a carefully constructed smiling alias - and also terrified by the equally present possibility of becoming the object of mockery hidden by a deactivated camera or in a private chat and of being dumped at any time by a simple click. Because we have no choice but to send these thin, fragile images of ourselves to work in our place, we have almost forgotten the unease that goes with constructing them in the first place. In Echographies of Television, written well before the invention of remote meeting technologies, Derrida described how uneasy he felt when surrounded by the technological devices needed to film an interview. His description sounds familiar to anybody who participates in today's digital meetings for the first time, or indeed has done so for a long time: "What is happening here when [we are] surrounded by this technical apparatus, all of a sudden, as if we had been interrupted, we had to start speaking in front of the camera and recording devices. A modification is produced - in any case in me, and I don't want to pass over it in silence - which is at once psychological and affective. Another process is set into motion, if you like. I don't speak, I don't think, I don't respond in the same way anymore, at the same rhythm as when I'm alone [...] or as when I'm with you...." Derrida was above all preoccupied by the transformations of time induced by such

1 Jacques Derrida and Bernard Stiegler, Echographies of Television, trans. Jennifer Bajorek (Cambridge: Polity Press, 2002), 70, see also 31-34. 
devices (the creation of an artificial present, the imposition of a rhythm, the ghostly possibility of encountering the dead in film ...) but also by the political, commercial and other conditions imposed by the devices themselves.

As I said, what interests me in this essay is not the digitalizing psyche and the shifting interplay between its protective vs. vulnerable layers. I will instead concentrate on the enhanced cognitive possibilities that make us adopt these devices in the first place, despite possible forebodings, and to show how the transcendental conditions of cognition have been complexified by placing the work of thinking in a digital setting. In what follows, I suggest explaining the pleasures and the frustrations brought about by total digitalization of life philosophically by discussing four transcendental illusions that underlie the experience of the digital world: the illusion of proximity, the illusion of presence, the illusion of total memory and the illusion of worldwide community.

As is well known, the term transcendental illusion stems from Kant, who had claimed that it is brought about by taking "a subjective necessity of a certain connection of our concepts on behalf of the understanding ... or an objective necessity, the determination of things in themselves" (A297/B253). ${ }^{2}$ A transcendental illusion is a "natural and unavoidable illusion which itself rests on subjective principles and passes them off as objective" (A298/B354). It is an illusion necessary to our epistemological projects, whose status should be regulative, not constitutive. The Critique of Pure Reason posits three necessary transcendental ideas: the soul, the world and God.

I will not delve into what Kant says of the soul, the world or God here but instead simply draw attention to the fact that a transcendental illusion is not an error but rather an idea that reason must project in order to guarantee its own coherence even though it knows the object of the idea lies beyond the bounds of possible experience. The reason accepts to play "as if" the idea was true because it knows it to be just an illusion. In the following, I will formulate the transcendental illusions of the digital world. In so doing, the problem of transcendental illusion is to some extent displaced or broadened, because these latter are not illusions projected by reason but illusions projected by sense (sense in all senses of the word: what can be sensed, what makes sense, what is sensible ...). In what follows, I will investigate four transcendental (or "quasi-transcendental") illusions of the digital world by drawing on Jacques

2 Immanuel Kant, Critique of Pure Reason, trans. Paul Guyer (Cambridge: Cambridge University Press, 1998), 386. On Derrida's use of Kant's notion of “idea," see Rodolphe Gasché's fine analysis in "Is Europe an Idea in a Kantian Sense", in Europe Beyond Universalism and Particularism, ed. Susanna Lindberg, Mika Ojakangas and Sergei Prozorov (Basingstoke: Palgrave Macmillan, 2014), 33-52. 
Derrida's work. Derrida does not have a full-fledged theory of digitality, but many of his concepts are useful in understanding the experience of the digital world.

However, I should first perhaps explain my decision to use Derrida as the main point of reference in a paper on specific technological devices. In the 2oth century, Derrida was not considered to be a central thinker in the field of the philosophy of technology, although his notion of "originary technicity," for example, attracted Simon Critchley's attention. ${ }^{3}$ However, a decade later, he was interpreted as a key thinker of the so-called "technological turn of contemporary philosophy" notably by David Wills and Arthur Bradley. ${ }^{4}$ Derrida has been criticized for paying too little attention to concrete historical technological formations, such as the remote meeting programs that have inspired this essay and for regarding them merely as instances through which general structures of différance can be studied. In Bernard Stiegler's interview with Derrida, published in Echographies of Television, Stiegler notes that Derrida analyzes the technologies of all epochs as instantiations of abstract structures of writing. He asks if Derrida sees any philosophically relevant changes as brought about by the history of concrete technologies and in particular what would be "the specificity of what you have recently given this name 'teletechnology'?" In response, Derrida says that all technics of writing are indeed teletechnologies for him and the essential is understanding these abstract structures, regardless of the epoch in which they are instantiated. He finds it difficult to answer to Stiegler's question concerning the specificity of contemporary technology directly, but by way of attempt, he says he suspects that if there is one, it would be rooted in the intensity with which past moments - what is dead - are today resurrected by the "living present" of "real time."5 Stiegler developed his criticism of Derrida's forgetting of the concrete history of technologies in his "Derrida and Technology: Fidelity at the limits of deconstruction and the prosthesis of faith." ${ }^{\prime 6}$ And Mark B. Hansen, for example, prefers Bernard Stiegler's thinking because it focuses on concrete technological systems, as does

3 Simon Critchley, Ethics - Politics - Subjectivity. Essays on Derrida, Levinas and Contemporary French Thought (London: Verso, 1999), 174-176.

4 David Wills, Dorsality: Thinking Back through Technology and Politics (Minneapolis: University of Minnesota Press, 2008), 3-4. Arthur Bradley, Originary Technicity. The Theory of Technology From Marx to Derrida (Basingstoke: Palgrave Macmillan, 2011), 110-111.

5 Derrida, Echographies of Television, $36-39$.

6 Bernard Stiegler, "Derrida and Technology: Fidelity at the limits of deconstruction and the prosthesis of faith," in Tom Cohen (ed.) Jacques Derrida and the Humanities: A Critical Reader (Cambridge: Cambridge University Press, 2001). 
Ben Roberts. ${ }^{7}$ On the contrary, Tracy Colony finds Derrida's approach more fruitful than Stiegler's precisely because Derrida aims at abstract structures like différance. ${ }^{8}$

However, one should not exaggerate the opposition between Stiegler's interest in concrete technologies and Derrida's preference for quasi-transcendental questions. Différance is not a pure ideal structure but coincides with the materiality of concrete inscriptions. Derrida underlines this, for example, in his rich reading of Paul de Man in "Typewriter ribbon: Limited Ink 2", where he actually expresses his own concept of materiality through a reading of de Man by adding "a timid contribution [...] by underscoring 'materiality, in place, so to speak, of 'matter,' then insisting on 'thought of materiality,' or even 'materialist thought of materiality,' in place, if I may put it this way, of 'materialist thought,' even within quotation marks." 9 This "thought of materiality" emerges as an answer to the question of whether it is possible to think the event and the machine at the same time (the coincidence between the two happens of course in writing). Both point at a kind of materiality: "there is no thinking of the event, it seems, without some sensitivity, without an aesthetic affect and some presumption of living organicity. [...] Moreover, it is difficult to conceive of a purely machinelike apparatus without inorganic matter."10 This "organicity" and this "materiality" do not mean any crude substantiality: they refer to the quasi-machinelike, "power of repetition, repeatability, iterability, serial and prosthetic substitution of self for self"ll that constitutes a specific kind of materiality that is "not something sensible or intelligible; it is not even the matter of a body [...] it is nothing and yet it works, cela œuvre, this nothing therefore operates, it forces, but as a force of resistance. [...] I would say that it is a materiality without matter."12 It is not, Derrida continues, a metaphysical concept of matter but "the artifactual nomination of an artifactual figure [...] almost a fiction."13 Such a concept of

7 Mark B. Hansen, "Realtime Synthesis' and the Différance of the Body: Technocultural Studies in the Wake of Deconstruction," Culturemachine vol. 6, 2004, Ben Roberts, "Stiegler Reading Derrida: The Prosthesis of Deconstruction in Technics," in Postmodern Culture, vol. 16, no. 1, 2005.

8 Tracy Colony, "Epimetheus Bound: Stiegler on Derrida, Life, and the Technological Conditions." Research in Phenomenology 41 (2011) 72-89, and "The Future of Technics". Parrhesia 27, 2017, 64-87.

9 Jacques Derrida, "Typewriter Ribbon: Limited Inc 2" in Without Alibi, trans. by Peggy Kamuf (Stanford: Stanford University Press, 2002), 8o.

10 Derrida, "Typewriter Ribbon: Limited Inc 2," 72.

11 Ibid., 133.

12 Ibid., 151.

13 Ibid., 153 . 
materiality as a withdrawal of intelligibility that needs to be presented in a quasi-fiction coincides with the notion of the khôra, which is the neither sensible nor intelligible, is both unreachable and incomprehensible, nonexistent but nonetheless there is or it gives (es gibt) a place of inscription ${ }^{14}$ that has come to signify Derrida's answer to the question of materiality. However, while the khôra is an abstract condition of thinking, the notion of materiality relies on the idea of artificial factuality - "artefactuality" - that may be artificial, but that is not if the artifice is not factual too.

Derrida analyzes teletechnologies through this notion of artifactuality and we can extend this to remote meeting technologies. Artifactuality also opens the question of the concrete political conditions of contemporary teletechnologies. Notably in his essay "Artifactualities," published in Echographies of Television, Derrida insists on the necessity of examining the political and economic conditions of teletechnological staging as well as the philosophical conditions of staging as such. "Like anyone trying to be a philosopher, I want very much not to give up either on the present or on thinking the presence of the present - nor on the experience of that which, even as it gives itself to us, conceals them."15

Although like Derrida, I am primarily interested in the abstract structures of sense and life, my starting point in this essay - and in part my aim - are the concrete technological systems that we find ourselves suddenly confronted with and whose epistemic implications and practical political consequences should not go unnoticed. Unlike Derrida, I do not focus on the artifactual scene of the television but on transcendental illusions projected by remote meeting software, that did not exist in Derrida's time. I want to show how, in this new situation, we can interpret new technologies with the help of Derrida's concepts and I also want to show how the new technological formations highlight new potentials in Derrida's concepts; curiously, the new technologies seem to illustrate Derrida's ideas even better than the ones he was familiar with.

What are the transcendental illusions of the digital world that can be conceptualized by drawing on Derrida's work?

14 Jacques Derrida, Khôra, trans. Ian McLeod, in On the Name (Stanford (CA): Stanford University Press, 1995), 89, 95, 97, 113. The first extensive treatment of the figure of khôra is John Sallis's Chorology, On Beginning in Plato's Timaeus (Bloomington: Indiana University Press, 1995).

Derrida and Stiegler, Echographies, 8. 
The word "digital" comes from the latin digitus, finger, and it still evokes a sense of having the world at your fingertips. Actually, the digital world could not function without this illusion of touching and commanding even distant things as if they were right in front of you. This is, of course, why our digital equipment has made things much easier during the CoviD-19 epidemics in comparison with the plagues of old. Hidden behind screens in order to protect ourselves from viruses, we have been able to act $a$ s if we were close to our interlocutors while being perfectly conscious of the illusory character of this proximity. Even when people sigh from Zoom fatigue and claim that everything was simpler and better when people could still meet in person without the mediation of screens and microphones, they know (if only they stop to think about it) that in-person meetings were not so easy, either, nor were they untroubled by distance. ${ }^{16}$ The digital meetings are interesting precisely because they make obvious the distance that was already there in the apparent immediacy of physical meetings.

Derrida analyzes the distance at the core of proximity especially in $\mathrm{On}$ Touching-Jean-LucNancy, where he retraces the history of touching. Touching has traditionally been understood as the sense of proximity that seems to give direct contact to things and to prove their concrete reality: insofar as you can be certain of what you can touch, touching provides evidence (the possibility of reaching evidence being the touching stone of philosophy ever since Descartes, ever since Husserl). ${ }^{17}$ "Touch, more than sight or hearing, gives proximity - it

16 A well-known example of the difficulty of physical presence is a famous scene from Wim Wenders's film Paris Texas in which two former lovers, who had been made raving, then mute by their too intense physical presence, could finally speak to one another only when they met in a peep show where they were separated by a tainless mirror that prevented them from looking directly at each other. Furthermore, in this intimate space divided into two solitary confinement spaces, they could only speak their heart's fill when turning their backs to the miserable screen and when speaking through microphones that brought their voices through cracking loudspeakers to the other side of the screen. Much could be said - and has been said - of the complex scenography of this heartbreaking scene, but one thing suffices here: a screen is never as simple as it seems to be, it reapproaches when it seems to separate, it dissimulates when it seems to reveal; similarly, a microphone is not as simple as it appears, for it distorts the very sound it that promises to carry into the most intimate interior cavity of the ear.

"The way of a theoretical touch, that is to say objective, knowing, exploratory in the epistemic sense of this word: touching in order to know, in view of the knowledge of an object: that which is before oneself but can thus also present itself to sight (the theorem) or that which resists and seems more appropriate for haptical objectivity; the privilege of the 
gives nearby."18 However, Maurice Merleau-Ponty and Jean-Luc Nancy in particular have shown that the apparent proximity of touching is actually based on a "haptocentric" illusion. ${ }^{19}$ They have underlined the distance that is at the heart of every contact: for there to be contact at all, there has to be at least two separate things between which the touching occurs and the dimension of touching is really this "between." Undoubtedly, in the moment of touch, the touching and the touched appear to be indistinct, as if they were momentarily fused with one another. Nonetheless one cannot speak of touching if there is not some gap between the touching and the touched such that, as Nancy says, "from one singular to another, there is contiguity but not continuity. There is proximity, but only to the extent that extreme closeness emphasizes the distancing it opens up. All of being is in touch with all of being, but the law of touching is separation: moreover, it is the heterogeneity of surfaces that touch each other. Contact is beyond fullness and emptiness, beyond connection and disconnection." ${ }^{20}$ Touching is the dimension of the "with" which really contains both the "proximity of the next" and the "simultaneity of distance and contact."21

In On Touching - Jean-Luc Nancy, Derrida only alludes to digitality, ${ }^{22}$ but we know from recent experience that the digital world provides a very good illustration of the distance at the heart of contact. The use of digital technologies is based on the illusion of proximity that is given to us by our screens, with which

theoretical touch has always been central in every philosophy of touch." Jacques Derrida, On Touching - Jean-Luc Nancy, trans. Christine Irizarry (Stanford: Stanford University Press, 2005), 76.

18 Ibid., 95 .

19 Ibid., 41, 156.

20 Jean-Luc Nancy, Being Singular Plural (Stanford: Stanford University Press, 200o), 5. Charlie Gere points out that unlike Nancy, Derrida is ultimately chiefly interested in the gap between touching and the touched in auto-affection, asking if "there is any pure autoaffection of the touching and the touched, and therefore any pure, immediate experience of the purely proper body, the body proper that is living, purely living. Or if, on the contrary, this experience is at least not already haunted, but constitutively haunted, by some hetero-affection, related to spacing and then to visible spatiality - where an intruder may come through, a host, wished or unwished for, a spare and auxiliary other, or a parasite to be rejected, a pharmakon that already having at its disposal a dwelling in this place, inhabits one's heart of hearts ... as a ghost." Charlie Gere, Community without Community in Digital Culture, (New York: Palgrave Macmillan, 2012), 55, quoting Jacques Derrida, On Touching - Jean-Luc Nancy (Stanford: Stanford University Press, 2005), 179-180.

21 Derrida, On Touching - Jean-Luc Nancy, 199, quoting Nancy, Being Singular Plural (Stanford: Stanford University Press, 2000). 
we are knowingly and willingly complicit. We know very well that on a computer screen, we precisely do not touch a concrete thing, we do not feel texture, warmth, elasticity, and the like. We touch glass or plastic and through them the only thing we reach is a symbol. Instead of touching, we manipulate and instead of a sensitive fingertip, we use a skilful hand. Like Nancy, Derrida thinks that touching and sensing is always already technical ${ }^{23}$ which invites us to ask whether technics - and what kind of technics - lies hidden in non-digitized, supposedly natural acts of sensing. The digital world functions by touching and it reveals that touching is not what we thought it would be: digitality makes manifest the distance and the separation that were always involved in touching and that, from having been minimal, have now become maximal. This has become very clear during the COVID-19 epidemic, where human contact has been replaced by Zoom, Teams, Meet, Skype and other surrogate meetings. It is "touching" to see a loved person, a friend, a colleague - and at the time to see him or her in the distance gradually creates craving for "real," that is to say organic touching, gestures, handshakes, hugs, kisses.

From this point of view, the digital screen that protects us from reality also isolates us from it. But from another point of view, distant things touch too. Let us now extend our reflection from the easy case of the things that are physically distant even though they seem to be present, to the complicated case of the things that come very close and even penetrate us even though they are so imperceptible that they seem to be absent. Digitality exemplifies this very well, when the very screen that is supposed to keep us safe from viruses exposes us to other kinds of infections, the best known of which are "fake news": false information and fickle affects. In Faith and Knowledge, Derrida indicates an analogy between "tele-technology" and threats to the immune system - in this instance between viruses and digitally transmitted "viral" messages and emotions. In order to explain the analogy, he refers both biological and digital virality to a general idea of "unscathed life" that he designates with the Latin-based word "munus" (that is at the root of "immunity" and "community"). ${ }^{24}$ As we

23 Ibid., 96-97. As Arthur Bradley says, "To Derrida's way of thinking, an originary technicity [...] always exists at the heart of the phenomenology of touch." See Arthur Bradley, Originary Technicity. The Theory of Technology from Marx to Derrida, 110-111.

24 As John W.P. Phillips says in his useful explication of Derrida's thinking on immunity and autoimmunity, in order to analyze two such different things as viruses and teletechnology in terms of immunity, Derrida needs "a notion that is irreducible whether we identify it in its biological or in its political forms: munus, a Latin commonplace (duty, gift, that which is owed as a priori payment for belonging) now secreted in a complex of related terms that include not only community and communication but also immunity and of course autoimmunity." (John W.P. Phillips, "Force and Vulnerability in Philosophy and Science. Husserl, Derrida, Stiegler," in Cultural Politics, vol. 11.2 [2015], 149). 
shall see in a minute, by protecting ourselves from the biological and digital viruses that jeopardize the "unscathed life" of body, spirit and community alike, we also create and maintain the illusion of the unscathed life which we need and which, at the same time, we would know to be an illusion, if we only stopped to think about it.

Biological and digital viruses illustrate the way in which a life can also be touched without knowledge and consent. Both digital and biological viruses attack the living organism from the outside, they are imperceptible agents that escape our notice and recognition and that are in this sense "distant" to perception - and yet they can slip into our living intimacy, become all too close without our noticing it, and thus remain imperceptible in us too. In other words, they can invade and infect us. This is how viruses, misconceptions and catchy emotions become alive and multiply themselves in us despite ourselves. Viruses and digitally-produced emotions are imperceptible and intangible, either too distant or too close for us to spot them and counter their action through hygienic measures or by arguments. One cannot argue for or against what one cannot identify: it slips through one's conscious defences and invades unconscious and nonconscious areas of one's thought. It imperceptibly contaminates us. Because we cannot perceive it, we cannot objectify it and therefore can neither verify nor falsify it: its way of acting is contamination and against it we can only trust the immune responses of our body, morality, and thus society.

But that is not all: this is a simplification based on the illusion of unscathed life. In Faith and Knowledge Derrida complicates the question further by showing that immunity does not only function by protecting a previously given, unscathed interiority from external threats ${ }^{25}$ but that more fundamentally it makes the difference between the sphere of one's own and the stranger in the first place, so that immunization produces one's own unscathed life as an effect, and not the other way round. Life can also develop autoimmune reactions in which it destroys its own defences (in autoimmune diseases) and is overrun by foreign bodies. ${ }^{26}$ If this is dangerous, the contrary to this too, a total immunity that would protect life from all exterior influences, is also perilous in that it would cut life off from the world and choke it to death. This is why

25 "This is indeed what the word 'unscathed' (indemne) says: the pure, non-contaminated, untouched, the sacred and holy before all profanation, all wound, all offence, all lesion." Jacques Derrida, Faith and Knowledge, in Acts of Religion, éd. Gil Anidjar (New York: Routledge, 2002), note $16,61$.

26 "The immunitary reaction protects the 'immunity' of the body proper against foreign antigens. As for the process of auto-immunization, which interests us particularly here, it consists for a living organism as is well known and in short, of protecting itself against its self-protection by destroying its own immune system." Derrida, Faith and Knowledge, 8 o. 
autoimmune reactions against immunity are also indispensable to life precisely because they expose and open life to external influences that it needs to live. Life really is this balancing act between immune and autoimmune reactions such that its "indemnification" is thus "a movement that is at once immunitary and auto-immune. The reaction to the machine is as automatic (and machinal) as life itself." 27 What really mediates these immune-autoimmune reactions in the case of human life is technics: technics is what mediates autoaffection both by healing and by hurting life. ${ }^{28}$ Technics is a medicinal-toxic pharmakon, a word that Derrida introduced in "Plato's Pharmacy" in an analysis of the technics of writing, but which can also be extended to all technics as Stiegler in particular has done:29

This dignity of life can only subsist beyond the present living being. [...] The excess above and beyond the living, whose life only has absolute value by being worth more than life, more than itself - this in short, is what opens the space of death that is linked to the automaton (exemplarily "phallic"), to technics, the machine, the prosthesis: in a word, to the dimensions of auto-immune and self-sacrificial supplementarity, to this death drive that is silently at work in every community, in every auto-co-immunity, constituting it as such in its iterability, its heritage, its spectral tradition. ${ }^{30}$

Another, more extended work would be needed to explain these extremely dense formulations in all the necessary detail. In the present context, however, drawing out their lesson for the question of digitality must suffice. We have seen that digital reality functions on the basis of an illusion of proximity, but when we look at this more closely, we see that this proximity harbors a distance within itself. Proximity is really an imperceptible distance best figured as contamination. It is not the distance between a subject and an object that enables a calm observation of the object. It is the imperceptible distance between a virus and its host, where the virus is always too distant or too close to be noticed before it begins to act. This is also true of the digitally-enhanced

27 Ibid., 81.

28 As Michael Naas puts it in his detailed commentary of Faith and Knowledge, "In order for life itself to continue to be vital, to live on, it must at once appropriate the machine (in the forms of repetition, the prosthesis, supplementarity, and so on) and reject it." Michael Naas, Miracle and Machine. Jacques Derrida and he Two Sources of Religion, Science, and the Media (New York: Fordham University Press, 2012), 202.

29 Bernard Stiegler, Technics and Time 1: The Fault of Epimetheus (Stanford: Stanford University Press, 1998).

30 Derrida, Faith and Knowledge, 87. 
life considered at the outset: its auto-affection takes place through the technical supplement that cannot be explained as just a simple object but that needs to be explained in terms of the immune and autoimmune reactions that it triggers. Our practical task is that of uncovering different (viral, digital) mechanisms of contamination. But uncovering these mechanisms also help us in our philosophical task: virality and teletechnicity exemplify the way of functioning of technics interpreted by Derrida in terms of prosthetics. A prosthesis is an aid and a threat to life, a pharmakon that aids objectivity and subjectivity without itself being objectifiable by a subject, a drug that is indispensable to the life that it infects. Realizing this makes easier our philosophical task of discovering the quasi-transcendental structure that viral and digital phenomena exemplify: the opening of différance exemplified by touching-from-afar.

\section{2 The Illusion of Presence}

The digital world has been designed as an optical world in which you see what you touch, and without seeing you could not orientate yourself in the digital space. ${ }^{31}$ (Fortunately there are intelligent solutions that convert digital contents for blind persons - but the general architecture of the digital world is based on an optical presupposition.) The digital world functions under this illusion of presence. Of course, we know through experience that the instantaneity of messages and news and the naturalness of images and video meetings are just useful but deceptive illusions (and we also know how to take advantage of this illusion by letting a black screen represent us when we are actually answering urgent mail).

Derrida has discussed the illusions of presence since his earliest works, in which he criticizes the "metaphysics of presence,"32 and perhaps most especially in many later works where he explores the "spectral" dimensions of any seemingly present encounter. He calls an unquestionably absent thing that appears and makes itself felt in the present moment a "spectre." Derrida's first example of such spectrality is the ghost of Hamlet's deceased father who appears to his son and calls upon him to avenge his murder. But later Derrida

31 Digitality thus illustrate the exchange between the haptical and the optical that Derrida indicates in On Touching - Jean-Luc Nancy: "Intuitive vision does not just come into contact, as it is said, it becomes contact, and this movement pertains to its nature. And further, its motion would go - its drive would extend rather from the optical (the scopical) to the haptical." Derrida then refers to the exchange between the optical and the haptical by Deleuze and Guattari. Derrida, On Touching - Jean-Luc Nancy, 123.

32 Especially Jacques Derrida, Speech and Phenomena, And Other Essays on Husserl's Theory of Signs, trans. David B. Allison (Evanston: Northwestern University Press, 1973). 
underlines that the domain of the teletechnological is the domain par excellence of spectrality: "the medium of the media themselves (news, the press, telecommunications, tele-techno-discursivity, techno-tele-iconicity, that which in general assures and determines the spacing of public space, the very possibility of the res publica and the phenomenality of the political) this element is neither living nor dead, present nor absent: it spectralizes. [...] It requires [...] hauntology."33

The digital world illustrates Derrida's point very well, because it shows that the main reason for the disintegration of presence in the digital world is the fact that what we see is really writing even when it looks like something seen. According to Derrida's well-known analysis (to the extent that it need not be reconstructed here) writing is by definition not the presence of a thing but the trace of the absence of a thing that has never been present. The digital world illustrates the structure of writing very well. Digitality consists in writing, not only in the digitized texts that we read, but also in the digitally reconstituted images and sounds, and most importantly in the code that carries and produces all symbols brought to our screens. Code consists in a text made of zeroes, ones, and algorithmic operations carried out on these - calculations that take place in microcircuits that are quite incommensurable with the signified contents displayed on the user-interface. The real stakes of Derrida's criticism of the metaphysics of presence were the uncovering of a dimension of writing (or "archi-writing") that enables sense formation. This theory of writing can also be used to explain the spectral effects of the hyper-real digital world. But Derrida's theory of writing could also be extended beyond the visible digital contents to the code and to the invisible calculative reverse side of the visible user interface in general, which has been examined by N. Katherine Hayles, Bernard Stiegler and Yuk Hui in particular. ${ }^{34}$ Fact-checking visible information does not amount to evaluating the invisible digital infrastructure itself: both affect us, but uncovering the hidden presuppositions of visible digital contents remains easier than unveiling the hidden presuppositions of the infrastructure of the system itself.

The illusions of proximity and of presence are related. Traditionally the senses of touching and seeing have been thought to provide evidence and

33 Jacques Derrida, Specters of Marx. The State of the Debt, the Work of Mourning and the New International, trans. Peggy Kamuf (New York and London: Routledge, 1994), 63.

34 See N. Katherine Hayles, Unthought. The Power of the Cognitive Nonconscious (Chicago: University of Chicago press, 2017); Yuk Hui, Recursivity and Contingency (London and New York, Rowman and Littlefield, 2019); Bernard Stiegler, The Neganthropocene, trans. Daniel Ross (London: Open Humanities Press, 2018). 
therefore to guarantee certainty. ${ }^{35}$ But as we have seen, digital media only mimic touching and seeing and thereby only produce the illusion of proximity and presence which can never attain the evidence that we attribute to physical reality. Digital technologies are part of what Derrida calls teletechnologies. As we saw, for Derrida digital technologies are the best examples of teletechnologies but they are not the only ones. All technologies of writing from handwritten notes to the Internet are teletechnologies: "The way in which I had tried to define writing implied that it was already, as you noted, a teletechnology, with all that this entails of an original expropriation."36 Still more generally, he interprets all technologies in the framework of writing. Teletechnologies are technologies in which texts, sounds and visions are necessarily staged; they recreate what Derrida calls an "artifactual presence" in which time is artificially produced as "real time" and the entire actuality is not given but artificially produced. ${ }^{37}$ Through remote meeting dispositifs and programmes we are provided with teletechnological interlocutors all over the world and in deferred times. Thanks to these technologies we can have the impression of being in the presence of people who are in fact not really in the "here and now" with us but are distant, ultimately no more or not yet, because these technologies provide

35 The iconic representation of touching as guaranteeing certainty is that of Saint Thomas who had to touch Jesus' wound in order to believe in his resurrection - only to learn that in order to carry out its touch, touching must not touch either as Jean-Luc Nancy shows through an interpretation of a painting by Caravaggio in Noli me tangere, trans. Sarah Clift (New York: Fordham University Press, 2008).

36 Derrida and Stiegler, Echographies of Television, op. cit., $36-39$.

37 "The time of this very speaking [in a filmed interview] is artificially produced. It is an artifact." Actuality is characterized by "artifactuality and actuvirtuality." This "actuality is, precisely, made [faite]; in order to know what it is made of, one needs nonetheless to know that it is made. It is not given but artificially produced, sifted, invested, performatively interpreted by numerous apparatuses which are factitious or artificial, hierarchizing and selective, always in the service of forces and interests to which 'subjects' and agents $[\ldots]$ are never sensitive enough. No matter how singular $[\ldots]$ actuality comes to us by way of fictional fashioning" (Derrida and Stiegler, Echographies of Television, 3).

However, even the really real time, time without technological mediations, is without pure presence: "What we call real time [...] is in fact never pure. What we call real time is simply an extremely reduced 'différance,' but there is no purely real time because temporalization itself is structured by a play of retention or of protention and, consequently, of traces: the condition of possibility of the living, absolutely real present is already memory, anticipation, in other words, a play of traces. The real-time effect is itself a particular effect of différance." (Derrida and Stiegler, Echographies of Television, 129.)

It is worth noticing that the idea of an artifactual presence has been developed in a very interesting fashion by Elsa Boyer in Le conflit des perceptions (Paris: MF, 2015). She shows, using a Husserlian framework, how computer games create not only artificial presences but they also extend, transform and finally create new stages that do not mimic any previous presence. 
us with a spectral presence even over the definitive distance of asynchronic past or future moments. Because teletechnological presence is thus produced and "artifactual," it cannot provide the simple evidence given by physical presence. Our relation to artifactualized objects cannot be that of evidence but it can only be that of faith and trust. For example, we need to trust in the artifactual stage of Zoom or Teams that present us to each other in digital meetings. ${ }^{38}$ We now know that we can usually place trust in such mediations and that it is thanks to them that we can place trust in each other as we do in online academic events. But we also know that the increase of technical mediation also increases the erosion of trust in the media and in political situations, for example, which we know are not devoid of manipulation and even falsification (such as "deep fakes"). (In the end, of course, we cannot make a clear distinction between academic, media and political events, but we can try to learn to judge the credibility of the artifactual stages wherein they are projected.)

In practical situations, thinking the illusion of presence means discovering, then judging and evaluating the conditions of artifactuality of teletechnological presence: in such situations, we must inquire into the conditions of trust in different technical settings that constitute our reality. Philosophically, however, teletechnologies are an eloquent illustration of the fact that if only presence can in the last instance guarantee evidence, showing that presence is actually constructed artifactually means showing that evidence itself is just a form of trust.

\section{$3 \quad$ The Illusion of a Complete Memory}

The digital archives that can be accessed via the Internet are presented to their users as a total memory that includes everything and forgets nothing. A critical user soon sees that this is not the case: innumerable old books, sounds, images, living memories, intimate experiences are missing from digital archives and even when such memories are digitized, they more often than not lose their original sense. Derrida's book Archive Fever shows why this is so: every memory

38 As Michal Naas shows in Miracle and Machine, "Technics is thus the possibility or the chance of faith [...] it is this same mystical foundation as belief or credit that founds both our techno-scientific knowledge and our faith in tele-technological performativity." (Naas, Miracle and Machine, 166). Naas interprets Derrida very well but situates his work in the context of religion, whereas like Martin Hägglund, I remain sceptical of the existence of a "religious turn" in Derrida's work and also read the theme of faith and trust solely in the context of technology. See Martin Hägglund, Radical Atheism, Derrida and the Time of Life (Stanford: Stanford University Press, 2008). 
archive is a finite set of traces, not a universal container of everything past. This is why every archive is an institution that is based on selective decisions to include this and exclude that, to organise some things in a determinate way and to leave others non indexed:

[T]he archive, as printing, writing, prosthesis, or hypomnesic technique in general is not only the place for stocking and for conserving an archivable content of the past which would exist in any case, such as, without the archive, one still believes it was or will have been. No, the technical structure of the archiving archive also determines the structure of the archivable content even in its very coming into existence and in its relationship to the future. The archivization produces as much as it records the event. This is also our political experience of the so-called news media. ${ }^{39}$

As Derrida and Stiegler's discussion in Echographies of Television add, it is inevitable that the archival contents are selected, and in itself this is not a problem but the criteria of selection can be a problem: 40 "Archive is no longer local and should no longer be simply national, so inheritance is no longer simply tied to a language, a nation, etc." ${ }^{41}$ Every decision concerning the access to and the rationale of the archive is also a political decision, even when archives extend further than national inheritance and when archiving is done in the name of the most universal principles such as "open science." ("Open science" is a catchy name that gives the impression that science is freely available to all; but as we know, the openness of science remains limited. Often the free online editions are machine-made compilations of poor quality, while the best scientific works are published as costly print editions or as digital editions that are behind paywalls and even patented. Besides the production of "open science" contents also takes place on an artifactual scene that has its own more or less transparent economic and editorial conditions).

What Derrida could not know but what has become increasingly important for us today is data-mining, where algorithms carry out data searches that are presented as capable of revealing unknown tendencies in the shared unconsciousness of humanity. Such algorithms are used by public, private and also

39 Jacques Derrida, Archive Fever, trans. Eric Prenowitz, Diacritics vol. 25, 2 (Summer 1995): 9-63, 17 .

40 Stiegler and Derrida refer to this problem particularly with respect to what companies (be they public or private) broadcast and what they do not and how what is broadcasted is staged (Derrida and Stiegler, Echographies, 41-43). They also refer to it with regard to national archives (ibid., 62-63).

Derrida and Stiegler, Echographies, 69. 
academic actors today. But these algorithms are not universal psychoanalysts and sociologists, they are only reflections of the interests and competences of their programmers and users. They can process much larger amounts of data than humans, but this is also why the information they gather cannot even in principle be verified by humans. This raises enormous epistemologi$\mathrm{cal}$ and ethical challenges. Even more far-reaching is the use of artificial intelligence capable of making decisions in the place of humans following their own, nonhuman types of inferences. When automatically generated decisions have impact on human lives and when those affected are unable to know the reasons why their case was decided in a certain way rather than another, this clearly poses significant ethical, juridical and political problems. ${ }^{42}$

In sum, studying the illusion of complete memory generated by our digital tools and especially by the Internet shows that digitality is not a universal container of everything past but merely a huge quantity of finite archives that are always created through limited choices. Today these archives are not just repositories of contents, but they are also equipped by automatic agents that interpret these contents for us. Our practical task, then, is to evaluate the epistemological and moral limits of such archives and of the "artificial intelligences" that interpret them. Our political task is to make visible the decisions that constitute the archives and the exclusions they generate. Our political task also extends to the evaluation of the material basis of the archive: what are the wanted and unwanted effects of the system infrastructure, the binary kind of logic, the erased but indispensable material substrate of the digital archive,

42 For a Foucaldian explication of "algorithmic governance" see Antoinette Rouvroy, who coined the term. Rouvroy, Antoinette \& Berns, Thomas. "Détecter et prévenir. De la digitalisation des corps et de la docilité des normes." https://works.bepress.com/antoi nette_rouvroy/3o/, 20o9, visited 26.9.2019; Rouvroy, Antoinette \& Berns, Thomas. "Le nouveau pouvoir statistique, Ou quand le contrôle s'exerce sur un réel normé, docile et sans événement car constitué de corps 'numériques' ...". Multitudes 40,1 (2010): 88-103. Chilling case studies of what happens when recruitment is done automatically are presented by Cathy O'Neil, Weapons of Math Destruction: How Big Data Increases Inequality and Threatens Democracy (New York: Crown, 2016). Even more impressive is Shoshana Zuboff's magnum opus that shows the impact of artificial intelligence in all areas of contemporary capitalist society. Shoshana Zuboff, The Age of Surveillance Capitalism. The Fight for a Human Future at the New Frontier of Power (London: Profile Books, 2019). I give a concrete example of the ethical consequences of algorithmic governance in my "Just Machines: On Algorithmic Ethos and Justice" in The Ethos of Digital Environments: Technology, Literary Theory, and Philosophy, ed. S. L. and Hanna-Riikka Roine (New York: Routledge, 2021). 
which is based on the exploitation of the workforce of poor countries and on the energetic system still principally based on the use of fossil fuels? ${ }^{43}$

A detailed examination of this complex network of political problems far exceeds the scope of this article. My aim is rather to refer to the complex dynamics of the digital archive, of which many people have recently become aware, in order to illustrate the autonomous nonconscious functioning of memory. In Archive Fever, Derrida illustrated memory primarily by the Freudian unconsciousness but he also pointed out that it should also be illustrated by the archival institution - whose nature is so well brought to the fore by the nonconscious digital archive - because the latter underlines the collective dimension of archival memory instead of just an individual memory. The structure of the digital archive also illustrates another core theme of Derrida's work. The very strategy of deconstruction is to read the history of philosophy as an archive (and not as representation of a transcendent ideal reality), that is, as discourses whose very materiality contributes to their sense. Because this materiality is defined as technicity and productivity, the autonomous functioning of the digital archive is an excellent illustration of the productivity of writing insofar as it both enables the use of the archive of philosophy and undermines its veracity and trustworthiness.

\section{$4 \quad$ The Illusion of Worldwide Community}

Digital tele-technologies are presented to their users as a world-wide network reaching and connecting all places of the world: they offer both universal communication and panoptic surveillance. Derrida says this in Faith and Knowledge as well as in his dialogue with Bernard Stiegler Echographies of Television, where the two authors consider tele-technologies as a vehicle of globalized capitalism, an issue that Stiegler continued to analyze as a serious threat to individual and collective individuation. However, the spaces that digital technologies open up to their users are neither truly intimate nor truly worldwide. The screens on which people are made present to each other in a video meeting only create a very thin sense of community. This illustrates the fact that the Internet is not a universal place, especially not a universal political space: it is a finite place of a common alienation.

43 See for example Jussi Parikka, "Deep Times and Media Mines: A Descent into Ecological Materiality of Technology" in Erich Hörl and James Burton, General Ecology, The New Ecological Paradigm (London: Bloomsbury, 2017). 
But it is still a community and it can illustrate an important albeit less evident feature of being-with in general. We know that remote meeting technologies offer the illusion of connecting their users, although in reality everybody remains where one is instead of getting to people, situations and places factually far from oneself (that is, instead of really exposing oneself to the strangeness of another situation). Digital tools displace us into spaces that are far from our intimate physical place into spaces shared by other similarly displaced persons. As these spaces are neither someone else's physical space nor are they of a truly universal scope, they are just what I have elsewhere called "displaces," ${ }^{4}$ places that are only made from displacements, from pure transitivity, that only enable the information transfer to other displaces. The artefactual digital scene is not a new $D a$, it is a difference kind of a place - a "displace." In the world of digital communication, a Dasein is not dislocated although it can receive "spectral visits" from other Da's. A "displace" is not a Dasein but it invites to rethink Dasein in function of the displaced "spectres" that haunt it.

Studying the illusion of the worldwide scope of digital world shows that although digital tools have the power to connect practically all places, it replaces physical places with abstract displaces where we only meet as "spectres." We need this community, and this is why pointing out the spectrality of the digital community does not amount to simply denouncing the alienation of our ghastly ghostly community - although, at times, this is the political task at hand. It also opens our philosophical task by inviting to make visible the spectral condition of being-with in general.

The principal aim of this article has been to illustrate and to push further a number of Derridean philosophical ideas that the digital world exemplifies strikingly. To conclude, however, I would like to say a last word on the political possibilities opened by Derrida's analyses. First of all, I would like to underline how fortunate we are to have these marvellous digital tools that allow us to work - and even work very well - even in times of epidemics. As long as the epidemic lasts, and certainly and to an even greater extent for long afterwards, we have no choice but to go on trusting in the "transcendental illusions of the digital world," because without these illusions our community would make far less sense. Derrida helps us to remember that these "quasi-transcendental ideas" that frame the present situation are regulative, not constitutive of the

44 According to Derrida, contemporary teletechnology excels in displacing places so that "the link between the political and the local, the topolitical, is as it were dislocated." (Derrida and Stiegler, Echographies of the television, op. cit., 57.) I develop the idea of the displace further in my "Technics of Space, Place and Displace" in Azimuth 10 (2018): 27-44, Special Issue "Intersections: At the Technophysics of Space." 
academic, working, and social life as a whole. The present exceptional situation invites us to elucidate certain aspects of work that may appear secondary in normal situations, but that are implicitly present in them too and that are also open to critique, not only in the sense of a topical cultural critique but also in the demanding Kantian sense of the term. The illusion of proximity, strikingly exemplified by digital devices, invites us to pay attention to technical mediations and the contamination mechanisms underlying sense-formation. The illusion of presence invites us to examine the grounds of our trust in artifactually staged significations. The illusion of complete memory reminds us that the archives that we are dependent on are always finite and that they call for constant critical reinterpretation. And the illusion of worldwide community emphasizes the limits of globalization, which is the proper dimension of academic life and of contemporary life in general, but which is nonetheless not a place where anyone can live. More than anybody else, Bernard Stiegler has attracted attention to the political dangers of the contemporary teletechnological setting. Although Derrida shares the gist of his critique, he also underlines the positive existential and theoretical possibilities of these technologies that Stiegler pointed to in his early texts, but that became minimized in his last texts, so marked by pessimism. This is why a Derridean reading of the digital world seems to be, not a rival of the more political reading, but a necessary complement to it. 